\title{
A PRÉ-HISTÓRIA DO RIO GRANDE DO NORTE
}

\section{THE PRE-HISTORY OF RIO GRANDE DO NORTE}

Valdeci dos Santos Junior

Ed. Brazil Publishing, 274 pp, Curitiba, 2020

ISBN 978-65-87836-88-1

\section{Resenha: Mônica Nogueira ${ }^{\mathbf{1}}$}

monica.aan@gmail.com

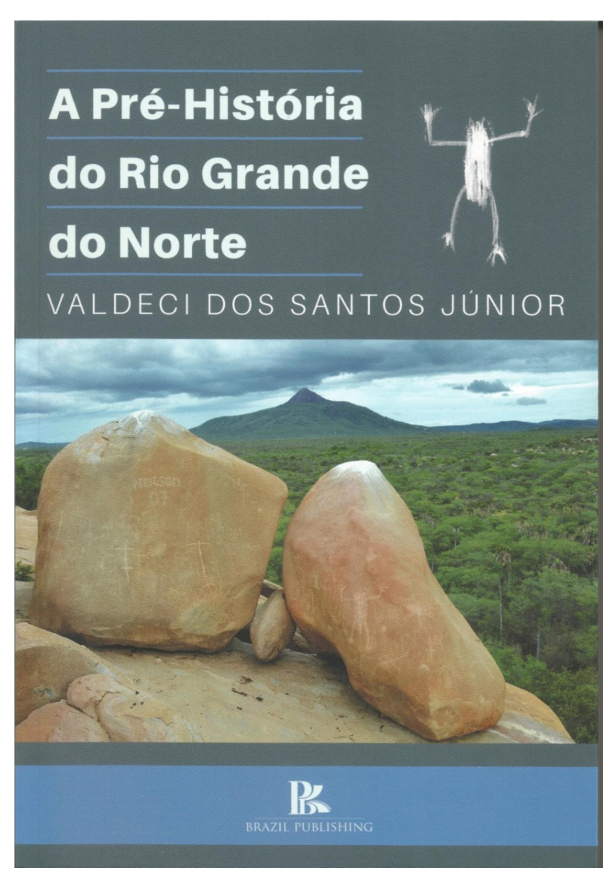

A Pré-História do Rio Grande do Norte, publicado pela Editora Brazil Publishing no ano de 2020 apresenta um panorama das pesquisas arqueológicas realizadas pelo Professor Valdeci dos Santos Júnior ao longo dos últimos 15 anos em todo o estado do Rio Grande do Norte, com especial foco na região Central Potiguar.

A obra é composta por 12 artigos científicos escritos em parcerias com diversos pesquisadores e que trazem uma discussão

1 Arqueóloga do IPHAN - AM. 
profícua sobre os mais diversos temas relacionados a arqueologia e a pré-história do Rio Grande do Norte, englobando desde registros rupestres (tema principal da obra), arqueologia da paisagem, análise de material lítico, remanescentes ósseos e a análise de um exemplar de canoa monóxila localizada na Lagoa de Extremoz, litoral norte-rio-grandense.

A diversidade temática, presente nesta compilação de artigos, demonstra a importância das pesquisas arqueológicas no estado para a compreensão da complexidade cultural das populações ameríndias que ocuparam aquele território desde os tempos mais remotos.

Dentre os artigos apresentados gostaríamos de chamar a atenção para dois deles. O primeiro "Datações de gravuras rupestres no Brasil" em autoria conjunto com a arqueóloga Daline Lima de Oliveira apresenta métodos para datações aplicados às gravuras rupestres e como a aplicação de tais métodos podem contribuir para a construção de uma cronologia para as ocupações humanas na pré-história Potiguar. Com o objetivo de se obter datações diretas para as gravuras rupestres do estado do Rio Grande do Norte foi utilizado o método da microerosão em painéis gráficos de cinco sítios arqueológicos. Apesar das diversas críticas aos métodos de datações de gravuras rupestres, principalmente àquelas obtidas por métodos diretos, o estudo e aplicação de tais técnicas em diversos sítios arqueológicos oxigena a discussão acerca dos estudos das gravuras rupestres em 
território brasileiro, e ainda tão pouco aprofundado pelos pesquisadores, como afirmam os próprios autores:

"A quase inexistência de pesquisadores/arqueólogos que se dediquem especificamente aos estudos das gravuras rupestres no Brasil é um fator limitante, principalmente com relação à ausência total de pesquisas cientificas (publicadas) com arqueologia experimental de gravuras em solo brasileiro. Penso que se essa ausência de pesquisas persistir (especialmente as voltadas para a arqueologia experimental), ainda continuaremos por muito tempo dependendo de eventuais e raras datações indiretas para obter cronologias dos registros gravados".

$\mathrm{O}$ segundo deles "Cadeia operatória e análise tecnológica: uma abordagem metodológica possível mesmo para coleções líticas fora de contexto" em autoria conjunta com Maria Jacqueline Rodet e Déborah Duarte-Talim apresenta uma importante reflexão metodológica para os estudos das coleções líticas a partir do conceito de Cadeia Operatória e da análise tecnológica e como tal metodologia pode ser aplicada em diversas coleções líticas, mesmo aquelas que não possuem informações de seu contexto in situ. Para tanto, foi utilizado como estudo de caso as pontas de projétil bifaciais que compõem a coleção do Museu Histórico Lauro da Escóssia, em Mossoró. Apesar das limitações impostas pela falta de contexto arqueológico para as peças líticas, a proposta apresentada traz à luz uma coleção que estava relegada ao esquecimento, possibilitando assim, outras abordagens e a construção de novas interpretações arqueológico quanto a tecnologia empregada para a confecção de tais artefatos, e como os próprios autores afirmam: 
"A intenção é demonstrar que a metodologia aqui apresentada pode ser aplicada em diferentes coleções líticas - mesmo aquelas que por estarem fora de contexto são, muitas vezes, esquecidas dentro das gavetas dos museus ou deixadas em segundo plano. Estas coleções podem, muitas vezes, trazer informações e aportes importantes às questões que se apresentam aos tecnólogos líticos".

Podemos afirmar que o livro do Professor Valdecir dos Santos Júnior, a partir da coletânea de artigos das mais diversas temáticas trata-se de uma tentativa bemsucedida de apresentar um panorama geral acerca da pré-história do Rio Grande do Norte, com numerosas reflexões do autor em relação aos métodos e técnicas empregados na arqueologia sem abrir mão da discussão teórica em busca de uma compreensão da complexidade das ocupações humanas pretéritas no estado. Tais reflexões tornam a obra uma importante referência para àqueles que estudam ou queiram se debruçar na arqueologia e pré-história do Rio Grande do Norte. 